Our results show that psychiatric patients had a longer interval between the onset of their symptoms and the surgical procedure. This may suggest that the patients postponed the search for medical care. An alternative explanation would be that their clinical symptoms could be erroneously attributed to their psychiatric disorder. A delayed diagnosis could be associated with more postoperative complications. ${ }^{2-3}$ In line with this, psychiatric patients had more complications than controls, although the length of hospital stay was the same for both groups. Other reasons for the increased morbidity in psychiatric patients in the postoperative period include: metabolic disorders related to the underlying disease or secondary to the use of psychiatric medications that have metabolic effects such as hyperglycemia, weight gain, and insulin resistance; inappropriate management of the psychiatric medication during the pre-, peri- and postoperative period, and the poor relationship among the members of the medical team (surgeons and psychiatrics).2,4

An interesting point that should be mentioned is the noninclusion of psychiatric patients in most studies that evaluate surgical indexes and features related to the morbidity and mortality of surgical procedures. ${ }^{5}$

Despite the evident limitations of our study (small sample, information obtained retrospectively and lack of laboratory or other clinical data possibly related to the outcome), the present results highlight the neglect of general medical problems in psychiatric patients.

Felipe Filardi da Rocha, Flávia Mello Soares, Humberto Correa

Department of Psychiatry, School of Medicine, Universidade Federal de Minas Gerais (UFMG), Belo Horizonte (MG), Brazil

Renata Figueiredo Rocha Service of Surgery, Santa Casa de Misericórdia Hospital, Belo Horizonte (MG), Brazil

Antônio Lúcio Teixeira Department of Internal Medicine, School of Medicine, Universidade Federal de Minas Gerais (UFMG), Belo Horizonte (MG), Brazil

Financing: None

Conflict of interests: None

References

1. Schneiderman G. Surgery and psychiatric practice. Can J Psychiatry. 1998;43(7):750.

2. Tsuang MT, Woolson RF. Mortality in patients with schizophrenia, mania, depression and surgical conditions. A comparison with general population mortality. Br J Psychiatry. 1977;130:162-6.

3. Cooke BK, Magas LT, Virgo KS, Feinberg B, Adityanjee A, Johnson FE. Appendectomy for appendicitis in patients with schizophrenia. Am J Surg. 2007;193(1):41-8.

4. Rocha FF, Bezerra BPS. Síndrome metabólica e transtornos psiquiátricos: uma associação que não pode ser esquecida. Arq Bras Endocrinol Metab. 2006;50(6):1138-9.

5. Abreu RA, Speranzini MB, Fernandes LC, Matos D. Feasibility analysis of loop colostomy closure in patients under local anesthesia1. Acta Cir Bras. 2006;21(5):275-8.

\section{More for the same?}

\author{
Mais pelo mesmo?
}

Dear Editor,

Andreoli et al. reported a significant decrease in the share for Mental Health (MH) in the Brazilian Public Health (SUS) budget. ${ }^{1}$ They refer to DATASUS as "limited", "unreliable", and unsuitable "for scientific purposes", as it fails to provide accurate information, for instance, on the number of psychiatric beds in general hospitals. Similar complaints were made in a recent audit performed by TCU, our High Court for Finances (www.contas.tcu.gov.br; Process 011.307/2004-9). The critical question is whether more investments should be made in the same model, as proposed by both publications.

Figure 1 shows 2,392 beds in 367 General Hospitals. However, 412 beds are in 224 hospitals with 4 or less beds. In the 90's, there were 2,156 beds in 139 General Hospitals. ${ }^{2}$ Clearly, Psychiatric Units in General Hospitals were never a priority.

Further information may help understand the budget issue:

1) Legislators and Government were told that community care was cheaper [e.g., "... a de-centralized model, with alternative, more efficient, more humane ... and less expensive..." (Sen. L. Alcântara report, 11/1995); ${ }^{3}$ or "... resources... channeled to other forms of care, less expensive and certainly revolutionary in their objective of socially including the psychiatric patient" (Sen. S. Rocha, 12/1998)]. ${ }^{3}$

2) Governments often divert money away from $\mathrm{MH}$ [e.g., "In many countries which adopted the deinstitutionalization policy, the community care is not reliable and is lacking in both financial and trained human resources ... many Ministries of Finance did not channel the budget of closed mental hospitals into other forms of mental health care services". ${ }^{4}$

3) According to the TCU audit, our MH system suffers from "severe managerial deficiency".

WHO praises the current CAPS-centric model (1,011 CAPS; only 37 open 24hs; 22,000 jobs; few psychiatrists; R\$ 168 million/year; never evaluated). However, it derives from "Il progetto dell'Instituto Mario Negri", the institution which sponsored the "Caracas Conference". ${ }^{5}$ In 2006, Brazil had 39,567 psychiatric beds (reimbursed at US\$17/day) or 2.2 beds/10,000 inhabitants ("Saúde Mental em dados 3", CORSAM, December, 2006). From the 120,000 beds supposedly available in the late 70 's, ${ }^{3}$ the reduction of 80,000 beds corresponds to $67 \%$ (actually, to $78.6 \%$, given the 65 million population growth), not just the recent $41 \%$ change. Moreover, 20,000 beds are currently used for long-term patients; modern medications are not reimbursed for bipolar disorders; and ECT is not recognized as treatment. Clearly, this system does not provide the most efficient care.

Patients are in the streets, jails and prisons, emergency services, or locked at home. TCU recommends modifications in the training of psychiatrists to conform to the "psychiatric reform". Conversely, severe criticism comes, among others, from the President of the Brazilian Psychiatric Association and from the President of the 2006 Brazilian Congress of Psychiatry (see Psiquiatria Hoje, December 2006). After two decades of "dehospitalization", we know that what needs reform is this failed $\mathrm{MH}$ model.

Valentim Gentil Department of Psychiatry, Universidade de São Paulo (USP) Medical School, São Paulo (SP), Brazil 


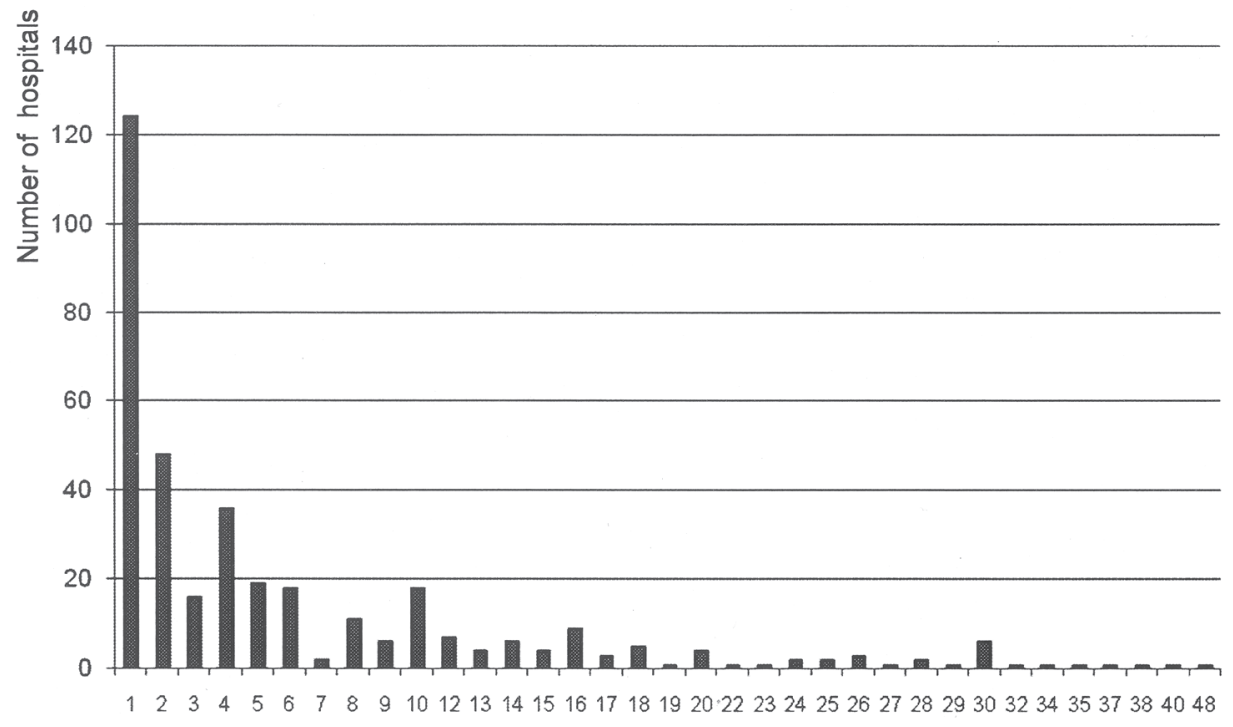

Number of beds

Figure 1 - Distribution of psychiatric beds in Brazilian general hospitals (Source: CNES/DATASUS; CORSAM, Ministry of Health, email dated 13/03/2007)

Financing: None

Conflict of interests: None

\section{References}

1. Andreoli SB, Almeida-Filho N, Martin D, Mateus MD, Mari JJ. Is psychiatric reform a strategy for reducing the mental health budget? The case of Brazil. Rev Bras Psiquiatr. 2007;29(1):43-6.

2. Venturini E. Prefácio. In: Amarante P (organizador). Loucos pela Vida. A trajetória da reforma psiquiátrica no Brasil. Rio de Janeiro: Fiocruz; 1995. p.136.

3. Proceedings and "Justification". Paulo Delgado's Project of Law. Diário do Congresso Nacional, June, 27, 1990 (available upon request).

4. Okasha A. Mental patients in prisons: punishment versus treatment? World Psychiatry. 2004;3:1-2

5. Saraceno B. II Progetto dell'Istituto Mario Negri: salute mentale in America Latina. Epidemiol Psichiatr Soc. 1994;3:49-58.

\section{A redução de leitos não significou redução do financiamento para a saúde mental no Brasil}

The decrease in the number of psychiatric beds did not mean the reduction in mental health budget in Brazil

\section{Sr. Editor}

Em relação ao artigo "É a reforma psiquiátrica uma estratégia para reduzir o orçamento da saúde mental? O caso do Brasil", ${ }^{1}$ a Coordenação de Saúde Mental do Ministério da Saúde tem duas considerações a fazer. Primeiro: os gastos totais, ao ano, do Ministério da Saúde (MS) com saúde mental aumentaram, em números absolutos, no período entre 1995-2006 (às custas do grande investimento nos equipamentos e projetos extra-hospitalares). Segundo: ao contrário do que informa o artigo, a proporção entre os gastos com saúde mental (GSM) e os gastos totais do MS (GTS) não caiu de $5,8 \%$ para $2,3 \%$ nos últimos 10 anos, mas manteve-se praticamente estável neste período.

Quanto ao primeiro ponto, não existem grandes divergências. Os autores do artigo reconhecem o incremento regular e sistemático dos recursos neste período. O segundo ponto, no entanto, merece comentários. No artigo, afirma-se que, de 1995 a 2006, houve redução da proporção gastos em saúde mental/gastos totais da saúde (GSM/GTS), de 5,8\% para 2,3\%. Os dados da Coordenação de Acompanhamento e Avaliação (CAA/Secretaria Executiva/MS) ${ }^{2}$ não autorizam esta conclusão. Em especial: os dados referentes às despesas totais do MS para o ano de 1995, informados pelos autores, são atípicos e radicalmente discrepantes em relação aos dados de orçamento anual do SUS disponíveis (ver Tabela 1) e às séries históricas de diferentes bases de dados.

A despesa geral do MS no ano de 1995, segundo os autores, teria sido de 6,5 bilhões de reais, contra cerca de 15 bilhões segundo a fonte CAA/MS (mais que o dobro do registrado pelos autores). Assim, a proporção GSM/GTS no ano de 1995 não representa 5,8\%, como afirma 0 artigo, mas 2,5\% dos gastos naquele ano, metade do que foi afirmado. Mesmo a baixa consistência das bases de dados agregados sobre financiamento de políticas sociais no Brasil não explica discrepância tão acentuada. Note-se também que os dados compilados pela Organização Mundial de Saúde (OMS) - AIMS Report on Mental Health System in Brazil 2006. WHO/Ministry

Tabela 1 - Valor total executado pelo Ministério da Saúde, de 1995 a 2006

\begin{tabular}{cccccccccccc}
\hline \multicolumn{10}{c}{ Valor total executado pelo Ministério de Saúde - em R\$ milhões } \\
\hline 1995 & 1996 & 1997 & 1998 & 1999 & 2000 & 2001 & 2002 & 2003 & 2004 & 2005 & $2006^{*}$ \\
$14.937,14$ & $25.376,79$ & $18.804,47$ & $19.323,69$ & $20.337,71$ & $22.699,25$ & $26.135,92$ & $28.293,33$ & $30.226,28$ & $36.538,02$ & $40.794,20$ & $44.342,74$ \\
\hline
\end{tabular}

*Estimado

Fonte: Coordenação de Acompanhamento e Avaliação/SEMS 